\title{
Social Capital and Banana/Plantain Production for Income Generation in Osun State: Rural Dwellers Experience
}

\author{
Stella O.Odebode and T.A.Adetunji \\ Department of Agricultural Extension \& Rural Development \\ University of Ibadan, Ibadan, Nigeria \\ E-mail: mrsdrodebode@yahoo.com; Tel: +234-8034891880
}

\begin{abstract}
This study examined the contributions of social capital to banana/plantain production in Irewole local Government Area, Osun State. The study also identified different social groups that respondents belong to. Multistage sampling technique was used to select the sample for the study. Three rural based wards were purposively selected while two villages from each ward were purposively selected. Making a total of 110 respondents selected.. Descriptive statistics such as pie and bar charts were used to summarize the data while inferential statistical tools such as chi-square and regression analysis were used to analyze the data. 36.0\% of respondents fell between the age group of 60-69 years. Banana/plantain producers were male dominated (94.0\%). $97.0 \%$ of the respondents belong to religious groups while $6.0 \%$ belong to non-governmental organization (NGO). Chi-square analysis showed that gender, marital status, age, religion, size of household, farm size and year of experience $(X 2=83.782,106.036,103.0,52.509,64.909,134.200$, 159.208; $P<0.05)$ were all statistically significant to contributions of social capital respectively. It is concluded that social capital contributed immensely to banana/plantain production among rural dwellers. Therefore, the use of social capital should be encouraged to complement the scarce financial capital, for enhanced food production.
\end{abstract}

Keywords: Social Capital, Banana/Plantain Production, Income generation, Rural dwellers.

\section{INTRODUCTION}

The use of collective action and interconnectedness among individuals to the upliftment of national economy particularly in agricultural production cannot be overemphasized. The concept of social capital according to Ejairu (2007) has become very significant in agricultural production due to the inability of formal financial organizations to take care of production capital requirement in agricultural production. Social capital is an important resource for individuals and organizations, as it compliments other resources that individuals and organizations control (Ahuja and Gautam, 2000). Different authors have conceptualized social 
capital but the concept is generally understood to be a social resource created through formal and informal relationship between people within a community (Coleman, 1990). Winter (2000) conceives social capital as a resource to collective action that may lead to a broad range of outcomes. On the other hand, Putman (2000) see social capital as connections among individuals, social networks and norms of reciprocity and trustworthiness that arise from them.

According to him, a society of many virtuous but isolated individuals is not rich in social capital. From the above definitions, social capital network in agricultural production in Nigerian context will include cooperative societies, Nongovernmental organizations, women groups, family labour, reciprocal labour and extension services (Ejairu, 2007). Picq C, Foure' E and Erison (1998) agreed that banana/plantain have potentials to contribute to strengthening national income, security and poverty alleviation. Social capital can be said to be an asset needed by banana/plantain producers to expand their production in order to boost their household food security and ensure sustainable livelihood contributing to the overall food security of the nation.

\section{Social Capital and Agricultural Production}

The idea of social capital has become very significant in agricultural production due to the inability of the formal capital institutions to take care of all requirements in agricultural production. Fafchsamps and Minten (2001) were able to identify some areas where social capital has played important role in agricultural production in India, these include:

- $\quad$ Farmer to farmer exchange of wilt resistant pigeon pea seeds, in the absence of state support for an appropriate and needed innovation in the viharbha and Marathwada, kinship community and other informal networks.

- The role of co-operatives in production and increasing adaptation rate of short duration pigeon pea in West Maharaghra, intensive farming, especially of sugarcane and other input, intensive crops in the irrigated tracts of the region.

- Co-operative introduction of legumes into cropping system.

- Seed multiplication by farmers' communal effort in the absence of government in Marathwada region of Maharaghra.

Most farmers in Nigeria operate on a small scale. The government in an attempt to boost agricultural production had set up various financial houses to make loan available to farmers in 2006 fiscal year. Farmers in the rural area still find it difficult to access this credit due to serious red-tapism. Hence, the only viable alternative left for farmers is what they get from social capital agricultural production. The basic ideas about social capital is that ones family, friends and age grades, neighborhoods constitute an important asset that can be called upon in production crises (Ejairu, 2007). To collaborate this view, Putman (2000) submitted that social capital is the benefits derived from the cultivation of good will fellowship, sympathy and social intercourse among which make up social units that help improve agricultural production. 
Banana/Plantain are the developing world's fourth most important global food crop after rice, wheat and maize in terms of gross value of production. The vast majority of producers are small scale farmers growing the crop either for home consumption or for local markets. As well as being a cheap and easily produced source of energy, they are also rich in Vitamin A, C and B6. Furthermore, with increasing urbanization, banana/plantain are becoming more and more important as cash crops, in some cases providing the sole source of income to rural populations, thus playing an important role in poverty alleviation (Picq et al., 1998).

Banana/plantain will also grow in a range of environments and will produce fruit all year-round, thus providing a source of energy during the "hungry-period between crop harvests. Although rural areas are naturally endowed with natural capital such as land and water and a level of acquired human capital that is required, still, as a result of experience in banana/plantain production over the years, they are often incapacitated by other kinds of capital such as adequate financial capital and social capital. These capitals are therefore required to turn the available natural resources and human capital into physical asset for increased production (The World Bank, 2007). The farmers require financial aids to meet increasing demands of production. Unfortunately, banana/plantain producers still find it difficult to afford collateral requirements and high interest rate charged by formal financial institutions. This hinders the average farmers from making any attempt to approach them for credit to improve and increase banana/plantain production (Ejairu, 2007).

Thus, a perceived alternative for raising financial capital needed for transforming the available natural resources in this area to physical assets is through the construction of social capital. This includes benefits accrued to individual by virtue of membership and participation in groups and group activities (Baron and Schuller, 2000).

Therefore, the study is providing answers to the following research questions:

- What are the selected personal characteristics of banana/plantain producers in the study area?

- What are the different social groups banana/plantain producers belong to?

- What is level of income realized from banana/plantain production in the study area?

\section{Objective of the Study}

The general objective of the study is to examine the contribution of social capital to banana/plantain production among the rural dwellers in Irewole Local Government Area of Osun State, Nigeria. Specifically the objectives were to;

- $\quad$ examine the selected personal characteristics of banana/plantain producers in the study area.

- $\quad$ identify the different social groups the banana/plantain producers belong to in the study area. 
- $\quad$ assess the level of income realized from banana/plantain production in the study area

\section{Hypotheses of the Study}

- There is no significant relationship between the selected personal characteristics of the respondents and contribution of social capital to banana/plantain production.

- There is no significant relationship between the selected personal characteristics and income level of the banana/plantain producers.

\section{METHODOLOGY}

The study was conducted in Irewole Local Government Area of Osun State. It is bounded in the north by Ayedire, in the south by Isokan, in the east by Ayedaade, and in the south east by Ife-North Local Government Areas of Osun state. It also shares boundary with Egbeda Local Government Area of Oyo state to the west. It is located within longitude $408 \mathrm{E}$ and latitude $707 \mathrm{~W} 30 \mathrm{~N}$; with a land mass of $978.67 \mathrm{~m} 2$. It has an estimated population of 143,599 with 74120 males and 69479 females. The vegetation cover of the Local Government Area is typically evergreen rainforest that is normally luxuriant during the rainy season. The major occupation of the people is farming, though some of them engage in some other occupations such as trading and commercial activities of all sorts like: bakery, transportation, sawmilling, plank selling, bricklaying and so on. The area is popularly noted for the production of plantain/banana, which is usually processed into what is known as Dodo Ikire. The target population of the study consists of all registered banana/plantain producers.

Multi stage sampling technique was used to select samples for the study. Out of the eleven electoral wards, three rural based wards which have the highest number of registered banana/plantain producers were purposively selected, then two villages from each ward which have the highest number of registered producers were also purposively selected making a total of six villages. A total of 110 respondents were randomly selected from the list of registered producers. The variables measured include selected personal characteristics and respondents were asked to indicate their gender, marital status, religion, household size, farm size, year of experience and also they were asked to indicate their actual age. They were also asked to indicate the social groups they belong.

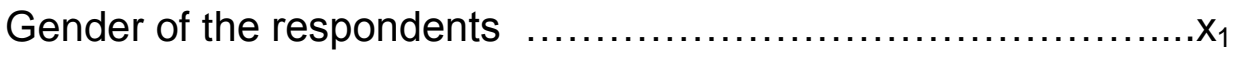

Age of the respondents......................................... $x_{2}$

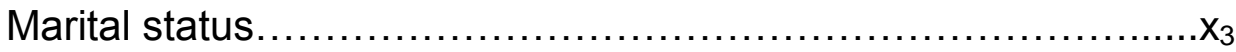

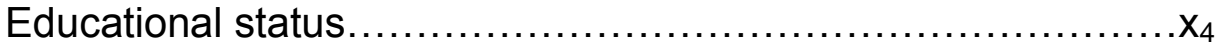

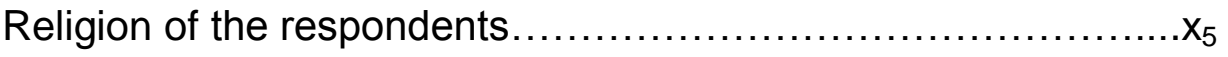

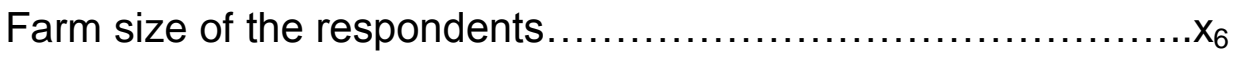

Household size of the respondents............................... 


\section{RESULTS AND DISCUSSION}

\section{Selected personal characteristics of respondents}

The result in fig. 1 shows that $36.0 \%$ of the respondents were between the age group of $60-69$ years while $17.0 \%$ were within the age group of $30-39$ years. This implies that most of the respondents are aged and have experience in banana/plantain production. However, in the nearest future, production may drastically reduce when these aged groups are no more. The findings also reveal that $94.0 \%$ of the respondents were male. The large proportion of male participation could be due to the fact that the most banana/plantain farming operations are undertaken by men and could also be due the fact that women do not have access to farmland like men. This implies that more efforts should be given to women participation and empowerment where women can come together in co-operative organization to enhance their access to utilization of agrarian resources. The finding reveals that $99.0 \%$ of the respondents were married. This implies that most of the respondents are independent, capable of taking their occupational farmlands to generate their own income. 


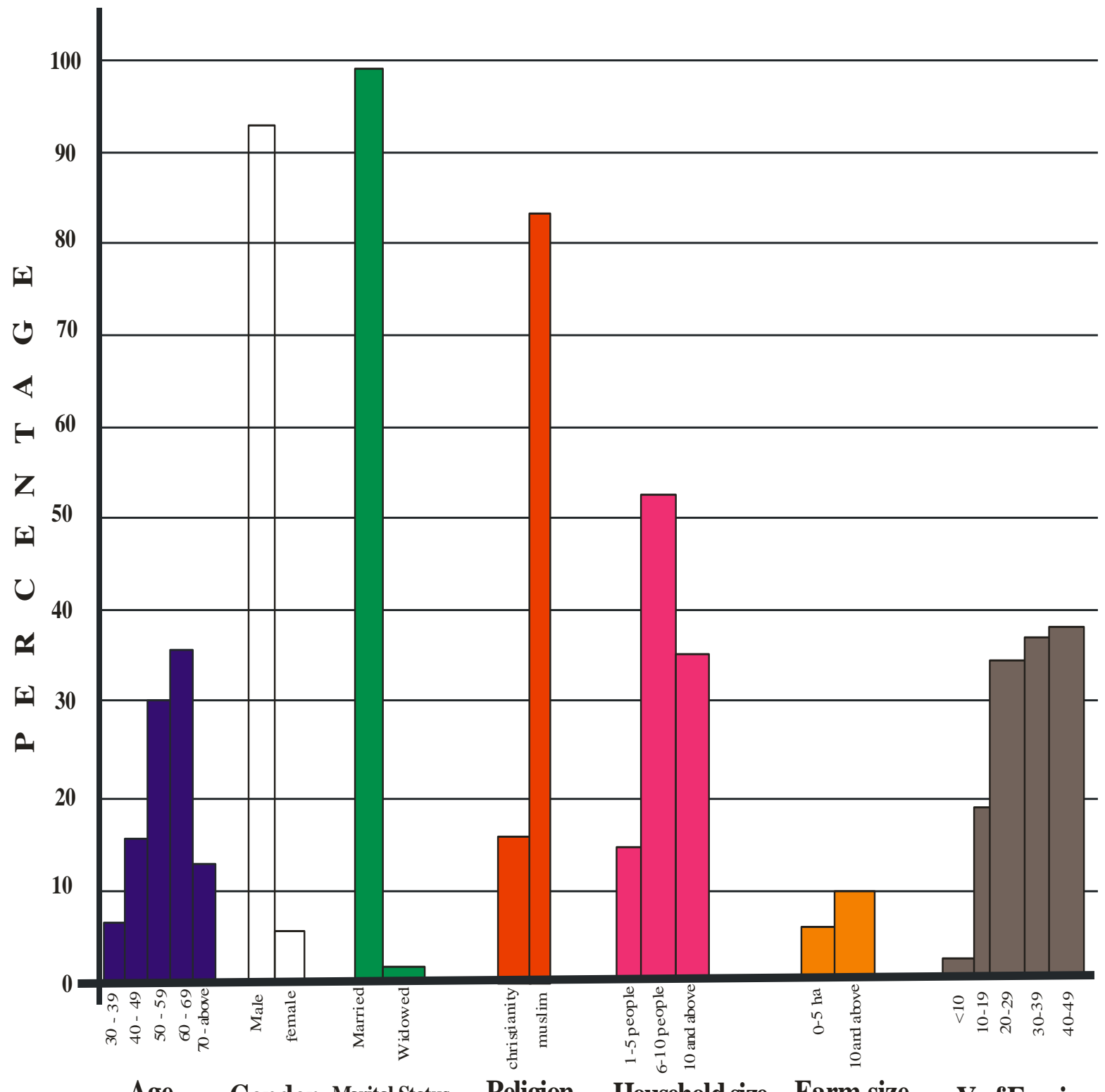

Age Gender Marital Status Religion Household size Farm size $\quad$ Yrof Experieme

Fig. 1: Frequency distribution of respondents based on their selected personal characteristics 

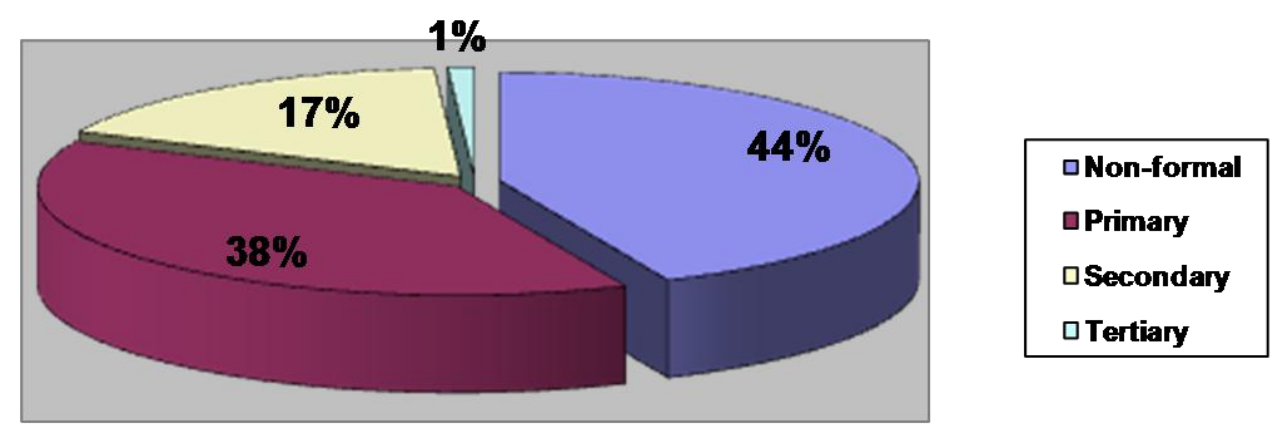

Fig.2: Educational Status of Respondents

The result also shows that $84.0 \%$ were Muslims while only $16.0 \%$ were Christians. Majority (51.0\%) of the respondents have a household size of $6-10$ persons which implies that an appreciable amount of farm labour would be met. Also $92.0 \%$ of the respondents have farm sizes between the range of $0-5$ ha which implies that the moderate farm size will earn them enough income to able to met family expenses. Meanwhile, for the years of experience, $53.6 \%$ respondents have put in between 10-29years in banana/plantain production while $44.6 \%$ have put in 30 years and above. This suggests that respondents have accumulated a lot of experience in terms of banana/plantain production; hence they are in position to improve on their farming activities. The result (fig.2) reveals that majority $(56.0 \%)$ of the respondents had one form of formal education or the other. Hence, this will influence proper management of their group activities by providing useful information for improved production.

\section{Membership of Social group(s)}

The findings in figure 3 reveal that $67.0 \%$ of the respondents belong to banana/plantain farmers association, $72.0 \%$ belong to trader/marketers association, $74.0 \%$ belong to co-operative society, $6.0 \%$ belong to a nongovernmental organization (NGO), $6.0 \%$ of the respondents belong to informal credit group and thrift society while $79.0 \%$ belong to daily contribution group, $6.0 \%$ belong to Fadama Community Association (FCA) and $97.0 \%$ of the respondents belong to religion groups. It can also be seen from the result that banana/plantain farmers associations, banana/plantain traders/marketers association, religious groups and co-operative societies have highest frequency of membership. This is indicative of the likely benefits derived by virtue of their membership in such socio-economic groups. Hence, social groups may be a good channel of information to the famers in the study area. 


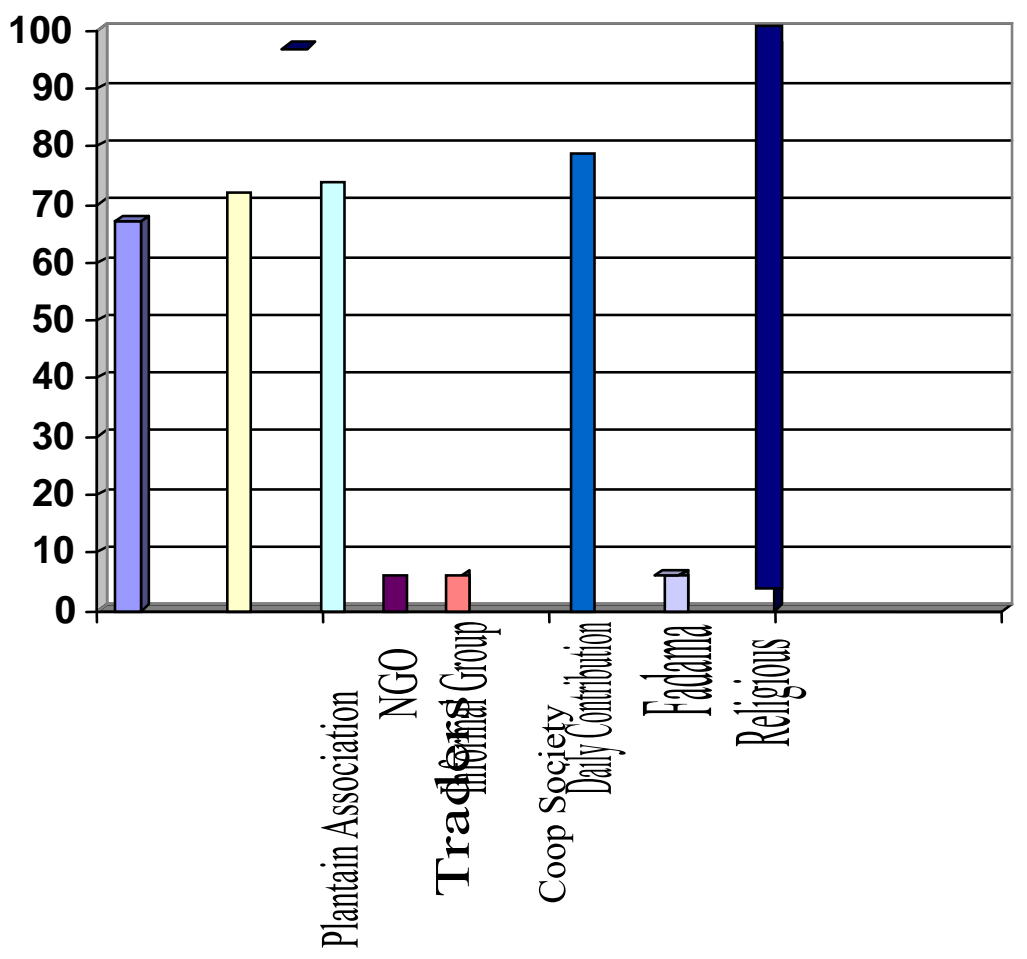

\begin{tabular}{|l|}
\hline Plantain Association \\
$\square$ Traders \\
$\square$ Coop society \\
$\square$ NGO \\
$\square$ Informal Group \\
$\square$ Daily Contribution \\
$\square$ Fadama \\
$\square$ Religious \\
\hline
\end{tabular}

Fig. 3: Membership of Social group(s)

\section{Level of income of respondents}

Figure 4 reveals that $36.0 \%$ of the respondents have low income level, $34.0 \%$ of the respondents fall within the moderate income level while $30.0 \%$ of the respondents have high income level. This implies that only some of the banana/plantain producers may have sufficient financial capital to take care of the production activities on the farm. However, the distribution of the respondents based on level of income is almost evenly distributed with little variation.
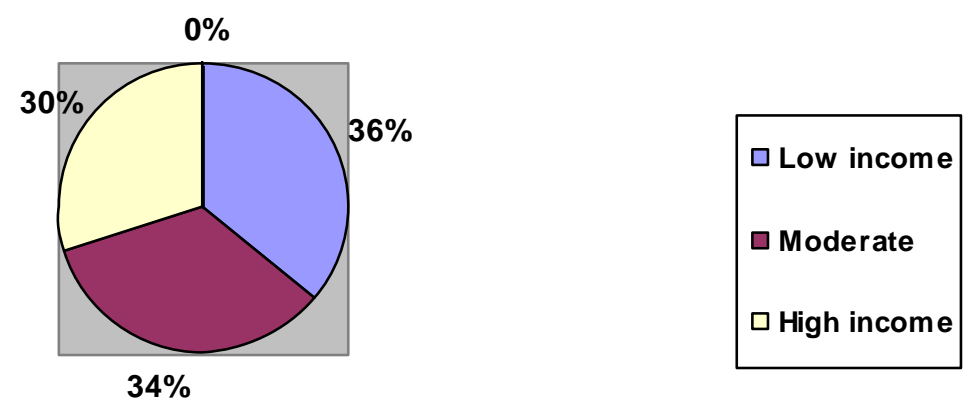

Fig. 4: Distribution of respondents based on income level 


\section{Contribution of social groups}

Table 1 shows that $36.4 \%$ of the respondents received information on input from banana/plantain farmers association, $59.1 \%$ of the respondents received information on marketing from trader association. Most of the respondents $(71.8 \%)$ received credit facilities from the cooperative society. Few respondents $(5.5 \%)$ received information from Non-governmental organizations on input, marketing, production, credit facilities and advocacy services. Most of the respondents (69.1\%) also received credit facilities from daily contribution group. This implies that respondents derived great benefits by being members of social group. In other words, social capital has enormous contribution to the well-being and level of production of banana/plantain producers.

\section{TABLE 1: Frequency distribution of respondents based on contribution of} Social capital

\begin{tabular}{|c|c|c|c|c|c|}
\hline \multirow[b]{2}{*}{ Social groups } & \multicolumn{5}{|c|}{ Frequency of benefit derived } \\
\hline & $\begin{array}{l}\text { Information } \\
\text { on input }\end{array}$ & $\begin{array}{l}\text { Information } \\
\text { on Marketing }\end{array}$ & $\begin{array}{c}\text { Information } \\
\text { on } \\
\text { production }\end{array}$ & $\begin{array}{c}\text { Credit } \\
\text { facilities }\end{array}$ & $\begin{array}{c}\text { Advocacy } \\
\text { Services }\end{array}$ \\
\hline $\begin{array}{l}\text { Banana/plantain } \\
\text { farmers } \\
\text { association }\end{array}$ & $40(36.4)$ & & & & \\
\hline $\begin{array}{l}\text { Traders/ Marketers } \\
\text { Association }\end{array}$ & & $65(59.1)$ & & & \\
\hline $\begin{array}{l}\text { Cooperative } \\
\text { society }\end{array}$ & $74(67.3)$ & $70(63.6)$ & $41(37.3)$ & $79(71.8)$ & \\
\hline $\begin{array}{l}\text { Non-Governmental } \\
\text { Organization }\end{array}$ & $6(5.5)$ & $6(5.5)$ & $6(5.5)$ & $6(5.5)$ & $6(5.5)$ \\
\hline $\begin{array}{l}\text { Informal Credit } \\
\text { and Thrift }\end{array}$ & & & & $6(5.5)$ & \\
\hline $\begin{array}{l}\text { Daily Contribution } \\
\text { Group }\end{array}$ & & & & $76(69.1)$ & \\
\hline $\begin{array}{l}\text { Fadama } \\
\text { Community } \\
\text { Association }\end{array}$ & $6(5.5)$ & $6(5.5)$ & $6(5.5)$ & $6(5.5)$ & $6(5.5)$ \\
\hline Religious Group & & & & $23(20.9)$ & $58(52.7)$ \\
\hline
\end{tabular}

Figures in parentheses are percentages 


\section{Relationship of selected personal characteristics variables and contribution of social capital to banana/plantain production}

The following variables such as gender, age marital status, educational status, religion, size of household, farm size and years of experience were tested for their relationship with the contribution of social capital to banana/plantain production. With the use of chi-square analysis in table 2, all the variables have significant relationship with contribution of social capital. In the chi-square analysis for gender $\left(X^{2}=83.782 ; P=0.00\right)$, the test of relationship is statistically significant. This implies that gender of respondents contribute significantly to social capital. However, the contingency significance value of this relationship is 0.30 . This implies that the strength of relationship is weak since the contingency significance is less than 0.5 . The strength of relationship is also weak for marital status and educational level while for age, religion, size of household, farm size and year of experience, the strength of relationship is strong since the contingency significance is greater than 0.5

TABLE 2: Chi-square analysis of relationship between selected personal characteristics and the contribution of social capital to banana/plantain production

\begin{tabular}{lccccc}
\hline \multicolumn{1}{c}{$\begin{array}{c}\text { Personal } \\
\text { characteristics }\end{array}$} & $\mathbf{X}^{\mathbf{2}}$ & Df & CC & P-Value & Decision \\
\hline Gender & 83.782 & 1 & 0.274 & 0.000 & $\mathrm{~S}$ \\
Age & 103.000 & 32 & 0.674 & 0.000 & $\mathrm{~S}$ \\
Marital status & 106.036 & 1 & 0.167 & 0.000 & $\mathrm{~S}$ \\
Educational status & 49.111 & 3 & 0.375 & 0.000 & $\mathrm{~S}$ \\
Religion & 52.509 & 1 & 0.632 & 0.000 & $\mathrm{~S}$ \\
Size of household & 64.909 & 19 & 0.579 & 0.000 & $\mathrm{~S}$ \\
Farm size & 134.200 & 10 & 0.502 & 0.000 & $\mathrm{~S}$ \\
Year of experience & 159.208 & 27 & 0.645 & 0.000 & $\mathrm{~S}$ \\
\hline
\end{tabular}

$S=$ Significant

Relationship of selected personal characteristics and income level of the banana/plantain producers

Ordinary Least Square regression was used to analyze the relationship between the selected personal characteristics of the respondents and income level. The income level of the respondents was regressed against the independent variables. 
The analysis in table 3 shows that gender, marital status and religion of respondents had no significant influence on their income level. However, age $(\mathrm{t}$ $1.18 ; p=0.04)$, educational status $(t=1.42 ; p=0.04)$, farm size $(t=-0.77 ; p=$ $0.02)$ and household size $(t=0.82 ; p=0.01)$ of the respondents had significant influence on the income level.

TABLE 3: Ordinary Least Square Analysis of Relationship between Selected Personal Characteristics and Income Level

\begin{tabular}{lllllllc}
\hline $\begin{array}{c}\text { Personal } \\
\text { characteristics }\end{array}$ & Gender & Age & $\begin{array}{c}\text { Marital } \\
\text { status }\end{array}$ & $\begin{array}{c}\text { Educational } \\
\text { status }\end{array}$ & Religion & $\begin{array}{c}\text { Farm } \\
\text { size }\end{array}$ & $\begin{array}{c}\text { House } \\
\text { hold } \\
\text { size }\end{array}$ \\
\hline Coefficient & 9.16 & 31.04 & 2074.00 & 676.65 & 224.75 & -112.32 & 42.96 \\
$\mathrm{t}-$ ratio & 0.01 & 1.18 & 0.93 & 1.42 & 0.29 & -0.77 & 0.82 \\
$\mathrm{P}$ & 0.07 & 0.04 & 0.24 & 0.04 & 0.77 & 0.02 & 0.01 \\
Decision & $\mathrm{NS}$ & $\mathrm{S}$ & $\mathrm{NS}$ & $\mathrm{S}$ & $\mathrm{NS}$ & $\mathrm{S}$ & $\mathrm{S}$ \\
\hline
\end{tabular}

\section{CONCLUSION}

A major conclusion of this study is that social capital contributes immensely to banana/plantain production among rural dwellers. It was observed that the contributions of social capital through membership in socio-economic groups such as co-operative societies, daily contribution groups, traders/marketers association as well as religious groups is high. This shows the level of importance attached to participating in group activities. In other words, the more social groups farmers belong to, the more the benefits accrued to them and such benefits include information on inputs, information on marketing, credit facilities and advocacy services.

Based on these findings, the following recommendations were made:

- Social capital should be encouraged and used to complement the scarce financial capital, available human and physical capital for enhanced food production.

- Innovative and educational programmes for social capital that are associated with agricultural production for effective mainstreaming of adequate agricultural support issues should be incorporated into agricultural and rural development programmes. Example is Fadama project in Nigeria.

- Extension activities should be intensified among the rural dwellers to ensure proper guidance of the rural dwellers forming social groups based on their needs.

- Youths should be encouraged to engage more in banana/plantain production 


\section{REFERENCES}

Ahuja and Gautam, (2000). Collaboration networks, structural holes and innovation: a longitudinal study. Administrative Science Quarterly Vol.45 pp $425-455$

Baron, S. and Schuller T. (2000) Social capital critical perspectives. United Kingdom Oxford University press pp 56-88.

Coleman J.C (1990), Foundations of social theory. Cambridge, M. A: Harvard University press pp $97-112$.

Ejairu O. (2007), Social capital investment on cassava production on Ethiope West Local Government Area of Delta State. Unpublished M.Sc Thesis in the Department of Agricultural Extension and Rural Development, University of Ibadan, Nigeria pp 113

Fafchamps M. and Minten B. (2001), Social capital and the agricultural trade. American Journal of FAO Vol. 47 №. 6 pp $12-25$.

Picq C, Foure E. and Erison E.A (1998), Banana and food security. International Symposium Soula, Cameroun pp 10-14

Putman R. (2000) Bowling Alone: The collapse and revival of American Community. New York.

Winter I. (2000), Towards a theorized understanding of social capital. Working paper21, Australian Institute of Family Studies.

World Bank (2007), Rural development and social capital. Retrieved September 19, 2007 http://www.worldbank.org/prem/poverty/capital/topic/rural/htm. 